\title{
The Push and Pull Factors of Migration - A Study of Migrant Construction Workers in Bangalore
}

\author{
Dr. B. SHAMALA \\ Associate Professor of Economics, Government First Grade College, Dharwad, Karnataka
}

\begin{abstract}
Migration, though has been an old phenomenon, more people are on move today than before. Most of the migrants are temporary in nature employed in the informal economy. Migration can be a choice or driven by economic factors, it can be formal or informal, migrants can either possess range of skills and capacities, low or high. Many push and pull factors contribute for migrating towards urban areas in search of better living conditions. The study tries to bring out the main factors that has been responsible for migration especially towards construction industry in Bangalore.
\end{abstract}

Keywords : Migration, Pull factors, Push factors.

\section{INTRODUCTION}

The country like India witnesses the migration of low income and economically backward people towards urban areas in search of better working conditions, higher income, better employment opportunities. The wide disparity in the development of regions forces the rural youth to leave the native and move towards other parts of the state or country. Many push and pull factors are responsible for the migration. The word Migration has been defined in different ways in various well known Dictionaries. According to the Oxford Advanced Learner's Dictionary of current English, Migration means to "move from one place to another (to live there)." According to the Webster's New World Dictionary, it means "move from one place to another, especially to another country." or "to move from place to place to harvest seasonal crops." According to Demographic Dictionary, "migration is a form of geographical mobility or spatial mobility between one geographical unit and another, generally involving a change in residence from place of origin or place of departure to the place of destination or place of arrival."

Many economic, social, geographical and other factors contribute for the migration of people from their native places. These factors can broadly be studied under two main headings 'Push' and 'Pull' Factors. But it is very difficult to understand which factors is more important push or pull? Some researchers argue that the push factor is stronger than the pull factor as they feel that it is the rural problems more than urban attractions that play a dominating role in the migration of the population. On the other hand, those who consider the pull factors as more important emphasize high rates of investment in urban areas leading to more employment and business opportunities and greater attraction for the urban way of life. But there are also a third category of researchers who argue that both push and pull factors are closely interrelated; those who are pushed into migration are simultaneously pulled by the expectation of finding something better elsewhere.

\section{PRESENT STUDY}

The present study tries to know which factors play a major role in determining migration of people. So, 400 migrant workers working in the construction sites in various parts of Bangalore were interviewed with structured questionnaire and the responses were analyzed to know the same.

\section{OBJECTIVES}

a. To analyze the Pull factors contributing for the migration of rural people towards urban areas.

b. To study the push factors responsible for migration of workers from their native places.

\section{HYPOTHESIS OF THE STUDY:}

In order to know the factors that are determining the migration the following hypothesis were framed.

a $\mathbf{H}_{0}$ : The Push Factors are not significantly responsible for construction workers to migrate towards construction industry. 


\section{International Advanced Research Journal in Science, Engineering and Technology}

Vol. 8, Issue 10, October 2021

\section{DOI: 10.17148/IARJSET.2021.81015}

$\mathbf{H}_{1}$ : The Push Factors are significantly responsible for construction workers to migrate towards construction industry. b. $\mathbf{H}_{0}$ : The Pull Factors are not significantly responsible for construction workers to migrate towards construction industry.

H1: The Pull Factors are significantly responsible for construction workers to migrate towards construction industry.

\section{METHODOLOGY}

The study is constructed on both primary and secondary data. The Secondary data was collected from the pertinent books, journals, magazines, labour commission report, labour department survey, and other important published as well as unpublished documents, thesis etc. With respect to primary data a structured questionnaire were used to gather the data from 400 workers (respondents) from different places of Bengaluru city. These 400 samples were selected using simple random sampling techniques. The study has covered specific information pertaining to the factors responsible for migration to the construction sector. To assess the push and pull factors the Likert Form of 1 to 5 has been used and the neutral value 3 has been compared to the mean score of all 400 respondents. For the single independent mean test the neutral value 3 has been considered as test value.

\section{REVIEW OF LITERATURE:}

Many studies have been already conducted on the migrant labour. Some of the important studies were reviewed and the output of each study have been presented systematically as follows.

Dadabhai Naoroji (1888) he pointed out various causes of migration of labour like agricultural poverty, the decline of village and cotton industries, poverty of the people, drought affected villages in which absence of work for about six months per annum and the existence of a large size of small cultivators whose holidays are extremely inadequate and landless labour in economically weaker sections of the community and lower caste people.

Lee's (1965) in his theory of volume of migration states that the "volume of migration within a given territory varies with the degree of diversity of areas included in that territory". Economic Criteria is the basic motive behind most of the migration.

Todaro (1969) tried to explain migration in developing countries in terms of push and pull factors respectively. Therefore, the motives of migration are classified as push factors and pull factors. Unemployment, flood, earthquake, drought (ie, natural calamities) etc, are the push factors. Pull factors that determine migration such as attraction of city life for education, health, development of backward community, job opportunities and training facilities and so on.

Richardson (1973) has observed that migrant tend to move from low wage to high wage areas and from areas of labour surplus to those with labour shortages.

Jayaraman (1979) brought out that variations in land holding alone do not determine the migration response. He observed that agriculture at the place of origin was dependent chiefly on rain and that agricultural activities were at a peak only during the monsoon months. Once the monsoon crop was harvested, agricultural activities nearly came to an end and the incidence of migration became more marked. The households did not have other activities to discourage migration in search of jobs.

Dyson and Visaria (2004) observe that India is experiencing several changes in its pattern of migration. Migration will become more urban oriented, but increasingly this will happen within expanding regional urban system. Movement to reside in a million plus city will be over shorter distances than applied in the past.

Binod Khadria (2006) said that the relationship between labour migration and poverty in India, during a period of rapidly growing inequalities. This is placed against the on-going debates on changes in the patterns of employment and job creation, during the period of economic Liberalisation, under the Inclusive Growth policies that are being followed since 2004, and under the impact of the global financial crisis.

Motiram and Singh (2012) examines the mobility in occupation across generations in rural and urban India by comparing the outcome of the sons with their fathers. They find "substantial intergenerational persistence, particularly in the case of low-skilled and low-paying occupations". Result implies the persistence of inequality of opportunity.

C. Sneka \& G. Vijayalakshmi (2016) found that, Unemployment and increasing poverty have prompted many workers in developing countries to seek work elsewhere, while developed countries have increased their demand for labour, especially unskilled labour. Lack of labour protection for migrant workers undermines protection generally for all workers One of the policy conclusions that national policy makers have drawn from these outcomes is the state should undertake efforts to prevent internal migration, through scheme such as rural employment programs.

\section{FACTORS RESPONSIBLE FOR MIGRATION TOWARDS CONSTRUCTION INDUSTRY:}

The study considered that there are two main factors responsible for migration to the construction industry from their native places. The two important factors are Push and Pull factors. Under push and pull factors many elements are considered and each factors are studied systematically as follows. 
DOI: $10.17148 /$ IARJSET.2021.81015

7.1 Push Factors influencing migration towards construction industry:

The push factors are treated as significant factors for the workers in forcing them to migrate to the construction sector in the study area from different places of their native. Opinion on each push factors are recorded in the table 1 and interpretations are given accordingly.

Table- 1: Details of the Push Factors influencing migration towards construction industry:

\begin{tabular}{|l|c|}
\hline \multicolumn{1}{|c|}{ Push Factors } & $\begin{array}{c}\text { Cumulative Percent of } \\
\text { Agreeable }\end{array}$ \\
\hline Landlessness & $84.5 \%$ \\
\hline Small holdings & $81.5 \%$ \\
\hline Crop Failure & $85 \%$ \\
\hline Rain fed Agriculture & $80 \%$ \\
\hline Drought & $89.8 \%$ \\
\hline Low wages & $8 \%$ \\
\hline Unemployment / Insufficient Jobs & $80.8 \%$ \\
\hline Indebtedness & $87.8 \%$ \\
\hline Less Civic Amenities & $80.8 \%$ \\
\hline Lack of Education & $87 \%$ \\
\hline Poverty & $86.5 \%$ \\
\hline Poor living conditions & $88.3 \%$ \\
\hline Poor Health care & $84.8 \%$ \\
\hline Unpleasant social relations & $87 \%$ \\
\hline Political intimidation & $85 \%$ \\
\hline High aspirations & $86.5 \%$ \\
\hline Poor life & $86 \%$ \\
\hline Demonstration effects & $86 \%$ \\
\hline Distress & $87 \%$ \\
\hline
\end{tabular}

Source: Primary data, Computed by the Author.

The table-1 depicts that 68.5 percent of the workers completely agree about the factor landlessness is responsible to push them to migrate towards the construction sector under the push factors as the study observed. The factor crop failure is also responsible as 85 percent of them have responded. Rain fed agriculture is also made them to choose this occupation in the construction industry as 80 percent of them have agreed to it. As 88.75 percent of the workers said that the factor drought has made them to migrate to work for the construction sector. The factor low level of wages has also influenced them to come and work in the construction sector as 77 percent of them have agreed and completely agreed. The factor unemployment of insufficiency of jobs also influenced them to migrate towards construction sector as 80.75 percent of the respondents have agreed. About 79.5 percent of the workers have completely agreed that the factor indebtedness has also made them to migrate to the sector. The respondents ( 78.75 percent) have accepted that the factor less civic amenities have stimulated them to migrate. Lack of education also inclined to migrate ( 87 percent). The element poverty is also one of the major factor in making them to shift to the construction sector from their native towns (86.5 percent). The poor living condition (88.25 percent), poor health care facilities (84.7 percent), the factor unpleasant social relations (87 percent), political intimidation ( 85 percent), high aspirations ( 80 percent), and Poor life ( 85 percent), and demonstration effects ( 87 percent) and distress ( 87 percent) are also responsible for forcing them to migrate towards the construction sector. It can be concluded that all these factors coming under push factors have been considered significant element for stimulating the workers to migrate towards construction sector.

\subsection{Pull Factors influencing migration towards construction industry:}

The present study also considered the pull factors to check their influences in making the construction workers shift towards the construction industry from their native places. Responses on each factor has been collected and presented in the table 2. Only the cumulative percentages are presented in the table and so has been able to understand and analyse the responses of the workers .

Table-2: Details of the Pull Factors influencing migration towards construction industry:

\begin{tabular}{|l|c|}
\hline \multicolumn{1}{|c|}{ Pull Factors } & $\begin{array}{c}\text { Cumulative Percent of } \\
\text { Agreeableness }\end{array}$ \\
\hline Better Employment & $88 \%$ \\
\hline Higher Wages & $82 \%$ \\
\hline Better Working Conditions & $84.8 \%$ \\
\hline
\end{tabular}


International Advanced Research Journal in Science, Engineering and Technology

Vol. 8, Issue 10, October 2021

DOI: 10.17148/IARJSET.2021.81015

\begin{tabular}{|l|c|} 
Job Security & $87.5 \%$ \\
\hline Implementation of Welfare Schemes & $87.5 \%$ \\
\hline Growth of Industries and Housing Sector & $83.5 \%$ \\
\hline Ample opportunities for business and trade & $82.8 \%$ \\
\hline Industrial centres & $82.8 \%$ \\
\hline Investment opportunities & $87.5 \%$ \\
\hline More civilized and better socio-economic conditions & $87.5 \%$ \\
\hline Better transport and communication network & $84.8 \%$ \\
\hline Availability of quality/standard education & $82 \%$ \\
\hline Better medical / health care facilities & $88 \%$ \\
\hline Better living conditions & $84.8 \%$ \\
\hline Better housing and other civic amenities & $82.8 \%$ \\
\hline Social and provisions and security & $89.8 \%$ \\
\hline Peace and prosperity & $79.5 \%$ \\
\hline Better recreation facilities & $84.8 \%$ \\
\hline Optimism and Growth & $82 \%$ \\
\hline
\end{tabular}

Source: Primary Data, Computed by the Author.

The table 2 clearly depicts that 88 percent of the construction workers have agreed about the factor that better employment opportunities in the urban areas have pulled them to migrate towards the construction sector as observed from the data collected. Higher wages ( 82 percent) is a very important factor for migration. The better working conditions ( 84.8 percent) always good for the workers and Job security also plays a crucial role in migration (87.5 percent), and again (87.5 percent) believe that implementation of welfare schemes can provide and increase the welfare of the workers in construction sector, the factor growth of housing and industries always attracts the migrants (83.5 percent), the element ample opportunities for business and trade (82.8 percent) significantly play a role in migrating the workers to the sector, as well as the factor industrial center has been considered as an imperative factor (82.8 percent). It is also interesting that the factor investment opportunities (87.5 percent) also provides a better platform for the workers and they migrate along with the family members, the factor more civilized and better socio-economic conditions is constantly playing its role in determining the level of migration (87.5 percent), the better transport and communication network ( 84.8 percent) can also be looked by the workers for migrating to the construction sector, the issue of availability of quality/standard education for their children (82 percent), better medical / health care facilities ( 88 percent), better living conditions ( 84.8 percent), Better housing and other civic amenities ( 82.8 percent), social provisions and security ( 89.8 percent), Peace and prosperity (79.5 percent), Better recreation facilities ( 84.8 percent) and the issue of optimism and growth factor ( 82 percent) have been highly inspiring the workers to migrate to the construction sector.

\section{HYPOTHESIS TESTING}

\subsection{Push Factors Responsible for Migration towards Construction Sector:}

$\mathbf{H}_{0}$ : The Push Factors are not significantly responsible for construction workers migrating towards construction industry. $\mathbf{H}_{1}$ : The Push Factors are significantly responsible for construction workers migrating towards construction industry.

Table-3: One-Sample Statistics for Push factors:

\begin{tabular}{|l|c|c|c|c|}
\hline & $\mathbf{N}$ & Mean & Std. Deviation & $\begin{array}{c}\text { Std. Error } \\
\text { Mean }\end{array}$ \\
\hline Landlessness & 400 & 1.6075 & 1.09611 & .05481 \\
\hline Small holdings & 400 & 1.9125 & 1.12383 & .05619 \\
\hline Crop Failure & 400 & 1.9550 & 1.02499 & .05125 \\
\hline Rain fed Agriculture & 400 & 2.0225 & 1.17279 & .05864 \\
\hline Drought & 400 & 1.7800 & .94011 & .04701 \\
\hline Low wages & 400 & 1.8000 & 1.03812 & .05191 \\
\hline Unemployment / Insufficient Jobs & 400 & 2.0600 & 1.06736 & .05337 \\
\hline Indebtedness & 400 & 1.5425 & .98010 & .04900 \\
\hline Less Civic Amenities & 400 & 2.0875 & 1.14810 & .05741 \\
\hline Lack of Education & 400 & 1.8025 & 1.08000 & .05400 \\
\hline
\end{tabular}


International Advanced Research Journal in Science, Engineering and Technology

Vol. 8, Issue 10, October 2021

DOI: 10.17148/IARJSET.2021.81015

\begin{tabular}{|l|c|c|c|c|}
\hline Poverty & 400 & 1.8375 & 1.04346 & .05217 \\
\hline Poor living conditions & 400 & 1.7300 & .91334 & .04567 \\
\hline Poor Health care & 400 & 1.7625 & 1.06721 & .05336 \\
\hline Unpleasant social relations & 400 & 1.6550 & 1.00922 & .05046 \\
\hline Political intimidation & 400 & 1.9300 & 1.03575 & .05179 \\
\hline High aspirations & 400 & 1.7950 & 1.07976 & .05399 \\
\hline Poor life & 400 & 1.8875 & 1.03563 & .05178 \\
\hline Demonstration effects & 400 & 1.8175 & 1.03773 & .05189 \\
\hline Distress & 400 & 1.8825 & 1.04231 & .05212 \\
\hline
\end{tabular}

Source: Primary Data, Sample Survey estimation.

Table-4: One-Sample Test for Push factors:

\begin{tabular}{|c|c|c|c|c|c|c|}
\hline & \multicolumn{6}{|c|}{ Test Value $=3$} \\
\hline & \multirow{2}{*}{$\mathrm{t}$} & \multirow[t]{2}{*}{ df } & \multirow[t]{2}{*}{$\begin{array}{c}\text { Sig. } \\
\text { (2-tailed) }\end{array}$} & \multirow[t]{2}{*}{$\begin{array}{c}\text { Mean } \\
\text { Difference }\end{array}$} & \multicolumn{2}{|c|}{$\begin{array}{l}95 \% \text { Confidence } \\
\text { Interval of the } \\
\text { Difference }\end{array}$} \\
\hline & & & & & Lower & Upper \\
\hline Landlessness & -25.408 & 399 & .000 & -1.39250 & -1.5002 & -1.2848 \\
\hline Small holdings & -19.353 & 399 & .000 & -1.08750 & -1.1980 & -.9770 \\
\hline Crop Failure & -20.390 & 399 & .000 & -1.04500 & -1.1458 & -.9442 \\
\hline Rain fed Agriculture & -16.670 & 399 & .000 & -.97750 & -1.0928 & -.8622 \\
\hline Drought & -25.954 & 399 & .000 & -1.22000 & -1.3124 & -1.1276 \\
\hline Low wages & -23.119 & 399 & .000 & -1.20000 & -1.3020 & -1.0980 \\
\hline Unemployment / Insufficient Jobs & -17.614 & 399 & .000 & -.94000 & -1.0449 & -.8351 \\
\hline Indebtedness & -29.742 & 399 & .000 & -1.45750 & -1.5538 & -1.3612 \\
\hline Less Civic Amenities & -15.896 & 399 & .000 & -.91250 & -1.0254 & -.7996 \\
\hline Lack of Education & -22.176 & 399 & .000 & -1.19750 & -1.3037 & -1.0913 \\
\hline Poverty & -22.282 & 399 & .000 & -1.16250 & -1.2651 & -1.0599 \\
\hline Poor living conditions & -27.810 & 399 & .000 & -1.27000 & -1.3598 & -1.1802 \\
\hline Poor Health care & -23.191 & 399 & .000 & -1.23750 & -1.3424 & -1.1326 \\
\hline Unpleasant social relations & -26.654 & 399 & .000 & -1.34500 & -1.4442 & -1.2458 \\
\hline Political intimidation & -20.661 & 399 & .000 & -1.07000 & -1.1718 & -.9682 \\
\hline High aspirations & -22.320 & 399 & .000 & -1.20500 & -1.3111 & -1.0989 \\
\hline Poor life & -21.485 & 399 & .000 & -1.11250 & -1.2143 & -1.0107 \\
\hline Demonstration effects & -22.790 & 399 & .000 & -1.18250 & -1.2845 & -1.0805 \\
\hline Distress & -21.443 & 399 & .000 & -1.11750 & -1.2200 & -1.0150 \\
\hline
\end{tabular}

Source: Primary Data, Sample Survey estimation.

The table 4 presented the output worked out on the push factors. The mean score for all the push factors for migration have been less than 3 . The likert form of 1 to 5 has been used for all push factors and the neutral value is considered as 3 and it has been compared to the mean score of all 400 respondents. For the single independent mean test the neutral value 3 has considered as test value. At 5 percent level of significance since $p<0.05$, the obtained single test value for all the push factors for migration is statistically significant. Hence, the mean score of push factors by all 400 respondents for migration is significantly less than 3 . It can be concluded that workers are significantly influenced by the push factors to migrate towards construction sector.

8.2 Pull Factors are responsible for migration towards Construction Sector:

Ho: The Pull Factors are not significantly responsible for construction workers migrating towards construction industry.

$\mathbf{H}_{1}$ : The Pull Factors are significantly responsible for construction workers migrating towards construction industry. 
International Advanced Research Journal in Science, Engineering and Technology

Vol. 8, Issue 10, October 2021

DOI: 10.17148/IARJSET.2021.81015

Table-5: One-Sample Statistics for Pull factors:

\begin{tabular}{|l|c|c|c|c|}
\hline & N & Mean & $\begin{array}{c}\text { Std. } \\
\text { Deviation }\end{array}$ & $\begin{array}{c}\text { Std. } \\
\text { Error } \\
\text { Mean }\end{array}$ \\
\hline Better Employment & 400 & 1.8100 & .98810 & .04940 \\
\hline Higher Wages & 400 & 1.9575 & 1.04567 & .05228 \\
\hline Better Working Conditions & 400 & 2.0025 & 1.02963 & .05148 \\
\hline Job Security & 400 & 1.8475 & .99837 & .04992 \\
\hline Implementation of Welfare Schemes & 400 & 1.8250 & 1.02567 & .05128 \\
\hline Growth of Industries and Housing Sector & 400 & 2.0050 & 1.10591 & .05530 \\
\hline Ample opportunities for business and trade & 400 & 1.9250 & 1.15008 & .05750 \\
\hline Industrial Centres & 400 & 1.9475 & 1.07826 & .05391 \\
\hline Investment opportunities & 400 & 1.8450 & .99924 & .04996 \\
\hline $\begin{array}{l}\text { More civilized and better socio-economic } \\
\text { conditions }\end{array}$ & 400 & 1.8375 & .95045 & .04752 \\
\hline Better transport and communication network & 400 & 2.0175 & 1.00982 & .05049 \\
\hline Availability of quality/standard education & 400 & 1.8525 & 1.19134 & .05957 \\
\hline Better medical / health care facilities & 400 & 1.6900 & .99819 & .04991 \\
\hline Better living conditions & 400 & 2.0100 & .98861 & .04943 \\
\hline Better housing and other civic amenities & 400 & 1.9375 & 1.18622 & .05931 \\
\hline Social and provisions and security & 400 & 1.7625 & .83836 & .04192 \\
\hline Peace and prosperity & 400 & 2.1750 & 1.01338 & .05067 \\
\hline Better recreation facilities & 400 & 1.9300 & 1.07143 & .05357 \\
\hline Optimism and Growth & 400 & 1.8625 & 1.12328 & .05616 \\
\hline
\end{tabular}

Source: Primary Data, Sample Survey estimation.

Table-6: One-Sample Test for Pull factors:

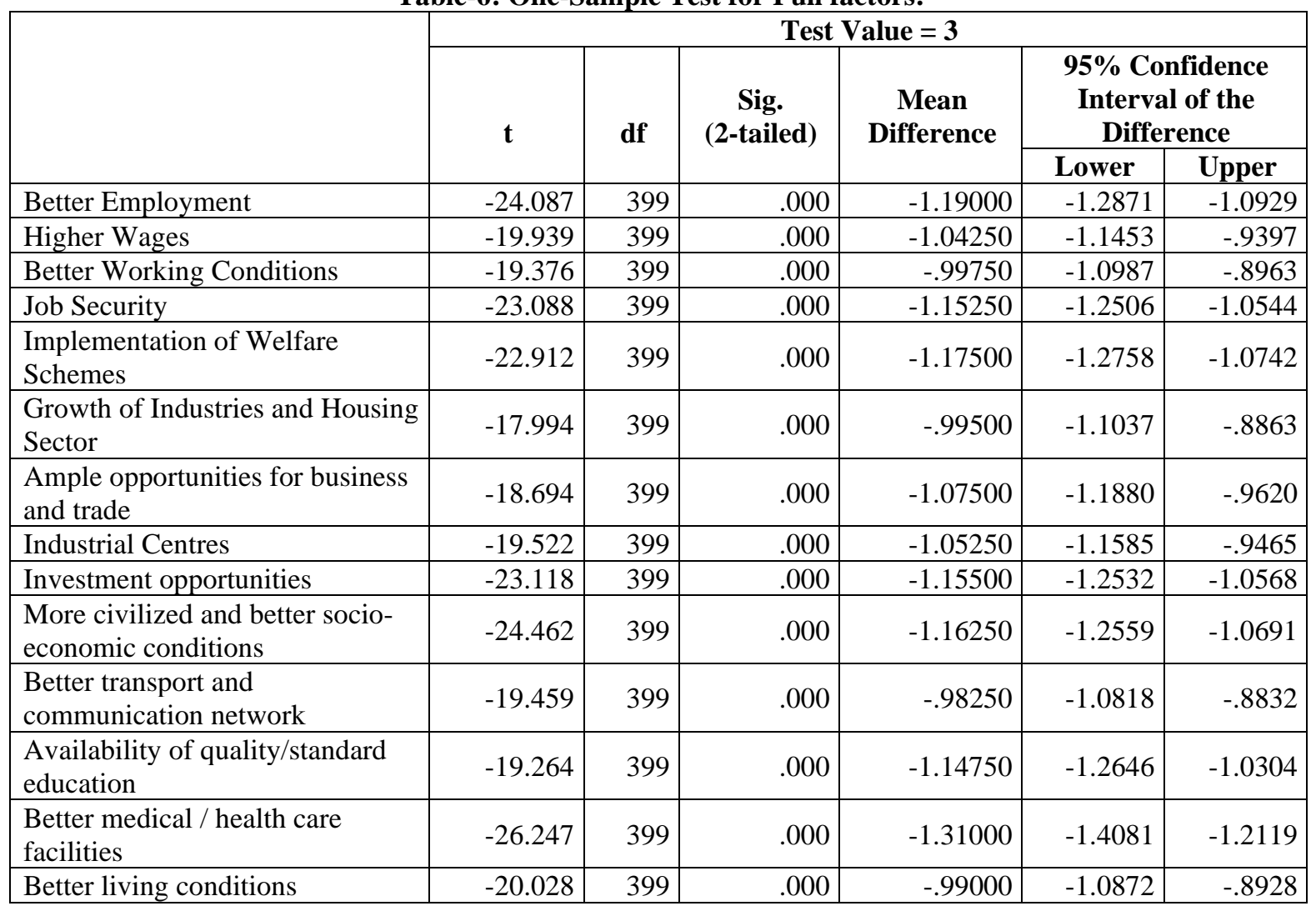


International Advanced Research Journal in Science, Engineering and Technology

Vol. 8, Issue 10, October 2021

DOI: 10.17148/IARJSET.2021.81015

\begin{tabular}{|l|r|r|r|r|r|r|}
\hline $\begin{array}{l}\text { Better housing and other civic } \\
\text { amenities }\end{array}$ & -17.914 & 399 & .000 & -1.06250 & -1.1791 & -.9459 \\
\hline $\begin{array}{l}\text { Social and provisions and } \\
\text { security }\end{array}$ & -29.522 & 399 & .000 & -1.23750 & -1.3199 & -1.1551 \\
\hline Peace and prosperity & -16.282 & 399 & .000 & -.82500 & -.9246 & -.7254 \\
\hline Better recreation facilities & -19.973 & 399 & .000 & -1.07000 & -1.1753 & -.9647 \\
\hline Optimism and Growth & -20.253 & 399 & .000 & -1.13750 & -1.2479 & -1.0271 \\
\hline
\end{tabular}

Source: Primary Data, Sample Survey estimation.

The mean score of all pull factors which are responsible for migration to the construction industry has been less than the neutral value 3 and it is the single sample test value. The average score for all push factors is less than 3 and it has been compared to the neutral value. The obtained test value for all pull factors is statistically significant at 5 percent level of significance. It is observed that the mean score of all 400 respondents is significantly less than 3 . It can be concluded that, all pull factors are significantly responsible for migration of the workers to the construction industry.

\section{CONCLUSION}

In conclusion this study has focused various aspects of push and pull factors responsible for migration towards construction sector. Since both push and pull factors are equally found to be responsible for migration from the study it can be said that an effective policy implementation by the government towards balanced regional development would control migration to a great extent. This would in turn reduce the problems of urbanization and its related issues.

\section{REFERENCES}

1 Binod Khadria, Parveen Kumar, Shantanu Sarkar and Rashmi Sharma, 'International Migration Policy: Issues and Perspectives for India', IMDS Working Paper Series, pp 1-20.

2 Dyson, T. and Pravin Visaria (2004); "Migration and Urbanization, Retrospect and Prospects", in Tim Dyson, Robert Cassen and Leela Visaria (eds), Twenty First Century India, Oxford: New Delhi, Pp. 108-129.

3 Guru Singh Kainth "Push and Pull Factors of Migration : A Case Study of Brick Kiln Migrant Workers in Punjab, Guru Arjan Dev Institute of development Studies, MPRA(2010)

4 Jayaraman, T.K. "Seasonal Migration of Tribal Labour: An Irrigation Project in Gujarat", Vol. XIV, No. 41, 1727-1732 Economic and Political Weekly, (1979)

5 Khandker S R, Khalily MB, Samad HA. 2012. Seasonal migration to mitigate income seasonality: evidence from Bangladesh. The Journal of Development Studies 48 (8): 1063-1083.

6 Lee's, 'Theory of Volume of Migration'.

7 Motiram S, Singh A. 2012. How close does the apple fall to the tree? Some evidence from India on intergenerational occupational mobility. Economic \& Political Weekly XLVII (40): 56-65.

8 Todaro, M.P. "A model of labour migration and urban unemployment in less developed countries", Vol.59, No.1 American Economic Review, (1969).

9 Richardson, H.W. "Resource mobility in the space economy" in H.W Richardson, Regional growth theory (The Macmillan Press Ltd, London, 1973)

10 Tushar Dakua (2019), 'Labour Migration', International Journal of Research in Geography (IJRG), Volume 5, Issue 1, 2019 , PP 9-26. 